\title{
6
}

\section{The Social Question in Pre-apartheid South Africa: Race, Religion and the State}

\author{
Jeremy Seekings
}

\section{Introduction}

In South Africa, as across much of the world, the period between the 1910s and 1940s was one of extraordinary intellectual as well as social and political turmoil. Not only were societies being rapidly transformed through migration, urbanisation and industrialisation, but there were competing and conflicting visions of "modernity". Intellectuals, elites and ordinary people alike grappled with the shifting relationships between state and society, as states were "modernised", old social institutions (including churches) lost some of their authority and new social institutions (including trade unions) emerged. Social relations — of gender, class and race-were contested and reimagined.

In contrast to the democracies of Northwest Europe, however, contestation over the social question in South Africa did not entail simply struggles over the form of social citizenship, as the state assumed an expanded role in the social and economic inclusion of citizens. In

J. Seekings $(\bowtie)$

University of Cape Town, Cape Town, South Africa

L. Leisering (ed.), One Hundred Years of Social Protection, Global Dynamics of Social Policy, https://doi.org/10.1007/978-3-030-54959-6_6 
Northwest Europe, social democracy emerged as a powerful ideology to address the social question, and existing conservative and liberal ideologies were reinvented. The working classes and the poor enjoyed considerable political power through the ballot box, strikes and the threat of direct action. Welfare states expanded, providing a considerable measure of social citizenship for all. This picture was reflected in South Africa with regard to one part of its population. But the majority of South Africa's population was excluded from social citizenship. The social question entailed exclusion as well as inclusion, with protracted debates and struggles over the boundaries of social citizenship-i.e. who is a social citizen-as well as the content and mechanisms of achieving it.

In some respects, South Africa was not unlike other parts of the world. In Latin America, most clearly, immigration, industrialisation and urbanisation defined the social question in terms of the inclusion of politically powerful groups — including the small, organised working class_-while excluding the larger population of urban and rural poor. The dominant corporatist ideology framed this combination of inclusion and exclusion (see especially Malloy 1979; Huber and Stephens 2012). Social citizenship across much of Latin America-as in the southern states of the USA — was racialised. South Africa was distinctive, however, in the extent to which social citizenship was fundamentally rooted in the country's racial politics.

The Union of South Africa was established in 1910 as the outcome of protracted negotiations following the British defeat of independent Boer republics in the South African War (see glossary at the end of the chapter for an explanation of South African terms including "Boer" and "coloured"). The new Union comprised the two former British colonies (the Cape and Natal) together with the two former Boer republics (of the Orange Free State and Transvaal). The political settlement provided for a substantially independent white-supremacist state, notionally under British control, with limited rights for the "coloured" population, very limited rights for the "native" African majority and almost no rights at all for the small immigrant Indian population. (White) Afrikaners comprised a majority of the electorate, with the result that the Union had three former Boer generals as prime minister for its first thirty-eight years (Louis Botha, 1910-1919; Jan Smuts, 1919-1924 and 1939-1948; 
J.B.M. [Barry] Hertzog, 1924-1939). The Union had a parliamentary system, with a prime minister accountable to a bicameral legislature. From 1910 to 1924, the government was run by the South African Party. The 1924 elections resulted in a "Pact Government" comprising the National (i.e. Afrikaner nationalist) Party and small Labour Party (linked to Labour Parties in Britain and Australia). The Pact Government disintegrated in 1933-1934, with most of the National Party joining the South African Party in a "Fusion Government", and then combining as the United Party. A minority of the National Party led by D.F. Malan remained independent, as the Gesuiwerde ("Purified") National Party. In 1939, many of the former National Party Members of Parliament (MPs) left the United Party over the issue of the Union's participation in the Second World War, joining with the Gesuiwerde National Party in a Herenigde (Reunited) National Party. In 1948, the National Party returned to government, with Malan as prime minister, and began to implement apartheid (see chapter by Ulriksen in this volume).

South African politics and society were defined primarily by white privilege. The white minority comprised approximately one-fifth of the population, including both farmers who had settled on the land and urban workers drawn to South Africa by the extraordinary industrialisation that followed the discovery of diamonds in the 1860s and gold in the 1880 s. The African population was largely rural, divided between whiteowned farms and the "reserves" set aside for "natives". Many African men worked at some point of their lives as migrant workers on the mines. Legislation restricted what work African people could do, where they lived and (above all) their political rights. Almost all white South Africans concurred that their hold on power should be preserved, but there was some disagreement over the flexibility of the boundaries of political (and, as we shall see, social) citizenship. There were also deep divisions among white South Africans over the division of power among them. An obvious cleavage divided Afrikaner nationalists from English-speaking South Africans as well as those Afrikaners who were reconciled with their loose incorporation into the British Empire. Class also divided the white population: Both English- and Afrikaans-speaking workers resented the extraordinarily wealthy mine owners (and their influence over the state). The commercialisation of agriculture also generated new class divisions: 
Many Afrikaans-speaking farmers lived on the edge of poverty; many of these "poor whites" migrated to towns. Without skills, they were unable to compete with either skilled white workers or unskilled African workers. The Labour Party, Afrikaner nationalist parties, communists, syndicalists and anarchists competed for the support of white workers. In 1922, white mineworkers on the Witwatersrand rose in violent rebellion (the Rand Revolt) before being suppressed brutally by the army and air force (Krikler 2005; Simons and Simons 1969; Greenberg 1980; O’Meara 1983; van der Walt 2011).

In this context, demands for policy reforms were understood in very diverse ways. There was little or no discussion of the "social question" per se, nor any consensus — even within white politics — over which of several other, interrelated "questions" was most pressing. The "native question" was clearly of great importance: Should African people, or some African people, be included in any way in a common society? If not, how should they be excluded? But there were other pressing "questions" also. The "poor white question" attracted considerable attention, not least because poverty among white people undermined the racial hierarchy and white solidarity. There was also a "labour" or "worker question" in that many (white) workers asserted their "rights" in relation to their (white) employers and some contemplated alternatives to capitalism. There was also the question of women's rights, not only to the vote but also to control over many other aspects of their lives.

For many (but certainly not all) white South Africans, the state was an attractive vehicle for tackling these questions in self-consciously modernist ways. The post-1910 South African state accumulated considerable infrastructural power: In the collection and use of statistics, fiscal capacity (including especially income taxes), strategic interventions in infrastructural and industrial development, the regulation of wages and employment, and with respect to the regulation of the family and the amelioration of poverty, all administered through a professionalised bureaucracy (Seekings 2016; Freund 2019). The South African state contrasted sharply with the "paper leviathans" of Latin America (Centeno and Ferraro 2013). Some white South Africans had grave reservations about this modern state. Some liberals welcomed many aspects of state support for business but were wary of what they saw as overreach. Neither 
anarchism nor syndicalism enjoyed as much support in South Africa as in some Latin American cities in the early twentieth century, but South African socialists and communists also had mixed feelings about a modern state that seemed to be closely tied to capitalist elites. More importantly, the powerful "Reformed" Protestant churches (including the largest, the Dutch Reformed Church, known by its Afrikaans initials as the NGK) included a variety of conservatives anxious to retain important roles for the churches. Whilst the NGK had long embraced a missionary role that encouraged charity, it also saw itself as a volkskerk (people's church), referring to the Afrikaner volk. In the late 1930s the NGK became more ambivalent about the state, in part through the spreading influence of the neo-Calvinist ideology associated with the Dutch theologian (and politician) Abraham Kuyper. Kuyper's theology revolved around the idea that different spheres of life (including the family) were all divinely sovereign, providing a new and powerful justification for restricting the scope of the state. The African population was unsurprisingly even more ambivalent about the role of the state, which they experienced as more repressive than progressive.

The result between the 1920s and 1940s was a gradual deployment of state power to address the "native", "poor white", labour and other (social) "questions", but the expansion of the state was shaped by the ambivalence and opposition of important sections of the white population. The battle lines in these contested reforms were often surprising, not least because Afrikaner nationalism was torn between modernisers who sought to use the state (including Hendrik Verwoerd, who was later to become the key architect of apartheid in the 1950s and 1960s) and NGK-linked opponents of state power. This shifting division within Afrikaner nationalism was to be especially important for social welfare policy. The result, by 1948 (when the National Party, by then committed to the apartheid project, was elected back into office), was a welfare state that had significant reach in terms of social assistance programmes and the regulation of the family (and delinquency) but not with respect to social insurance.

This chapter charts policy reforms and identifies the underlying understandings and motivations of key reformers (and their opponents) in three broad periods: The period of the Pact Governments from 1924 to 1933; the period of the Fusion or United Party governments from 
$1933 / 34$ until the outbreak of war in 1939; and the period during and immediately after the war, also under United Party governments but with growing opposition from an opposition National Party radicalised in part by new religious beliefs.

Whilst the conditions framing debates in South Africa might have been unique, the South African participants in these debates were immersed in global networks of ideas. At every point, South African debates were informed by ideas and models from elsewhere. The South African state followed the British lead in using commissions of inquiry to investigate possible policy reforms. These commissions typically collated a mass of information on policies elsewhere in the world (and generally summarised these in their reports). When, in the late 1920s, the Pienaar Commission investigated welfare policy reforms, it drew heavily on information provided by the International Labour Organization (ILO), as well as information from Britain and elsewhere. Several members of the commission visited the ILO in Geneva, attended one of the ILO's annual International Labour Conferences and visited various European capitals in order to collect additional information. In addition, many prominent South Africans studied abroad. Prime Ministers Smuts and Hertzog studied in Cambridge (1892-1894) and Amsterdam (1888-1892), respectively. Others who played important roles in policy debates included Jan Hofmeyr (Oxford, 1913-1916), E.G. Malherbe (New York, the early 1920s) and Hendrik Verwoerd (mostly in Germany, 1926-1928). Individual Members of Parliament (MPs), trade unionists and academics travelled and had contacts elsewhere in the world, especially in Australia and New Zealand. For all these reasons, innovative foreign reforms and proposals had immediate and wide impact within South Africa. In the early 1940s, as we shall see, reforms in New Zealand and the proposals set out in the Beveridge Report in Britain framed South African debates. American ideas about social casework also had a strong influence. Not all foreign ideas strengthened reforms, however. Many Afrikaner nationalist theologians studied at the neo-Calvinist Free University in Amsterdam, founded by Kuyper. 


\section{Securing the Racial Hierarchy, 1924-1933: State, Church and the "Poor White Problem"}

Prior to 1924 the state's involvement in social regulation and provision expanded slowly but remained very limited. The South African Party governments in office from 1910 to 1924 were broadly pro-business. The state provided modest poor relief, almost entirely for "poor whites", supplementing the charitable work of churches (Bottomley 1990; Butler 2017). Compensation was introduced for the (white) victims of industrial accidents. The 1913 Children's Protection Act-based on British legislation from 1908 - provided for the state to place (white) children in need of care in institutions and for state subsidies to both these residential institutions and churches or other child welfare societies that oversaw other children in need of care. In 1921, pensions were provided to (mostly white) mothers (as well as stepmothers and grandmothers) who had been widowed or abandoned by their husbands, to reduce the need to place destitute children in residential institutions (Du Toit 2018; Chanock 2001). Reformatories and industrial schools were also established for (mostly white) boys and girls (Chisholm 1990).

These reforms were racialised in intent. White families organised around Christian marriage were seen as a bulwark against the degeneration of the white population. It was when white men disregarded their obligations to their wives and children that children were neglected, dropped out of school and thus rendered unfit to compete for jobs against coloured or African people. Flawed families meant that girls risked sliding into prostitution, and poor white men and women risked sinking into "a demoralising and corrupt intercourse with non-Europeans", as a parliamentary committee put it. The 1913 Children's Protection Act thus sought to maintain the "boundaries of whiteness" (Chanock 2001: 205-209). Under the 1913 and 1921 Acts, it was hard for coloured children or their mothers to access benefits and almost impossible for African children or their mothers to do so. Sexual "impropriety" - typically across racial lines - was the main reason for white girls being placed in institutions (Chisholm 1990). The protection of the white family—and hence 
white supremacy-required intensified segregation to limit mixing between white and non-white children.

Reforms accelerated under the Pact Government elected in 1924. The Pact Government comprised the National Party, based in poor rural areas, and the ostensibly socialist Labour Party, whose core support was among skilled urban workers. These parties had broadly antagonistic relationships with the mining companies and other large businesses. The National and Labour Parties had campaigned on platforms for tackling both the "poor white problem" and the excessive profits of mining capitalists. Solving the poor white problem meant protecting unskilled white workers (and their dependents, in both rural and urban areas) who lacked the skills required for skilled employment and were unable to compete for unskilled work with cheaper African labour. The National and Labour parties had accused the then governing South African Party of jeopardising the future of white South Africans "as a civilised people" and pandering to "big financial" interests. The National Party was unashamedly racist. The Labour Party comprised both unabashed racists and socialists who felt uncomfortable with explicit racial discrimination but were opposed to the exploitation of "cheap labour".

In office, the Pact Government sought to deepen racial segregation, not only keeping white and African people apart but also protecting poor white people from competition from African people. The colour bar in employment was strengthened, and parastatals (especially the railways) were instructed to employ unskilled white workers. Subsidies were extended for white farmers, especially on smaller or family farms. The Labour Party secured regulatory institutions that protected workers' wages (along the lines of policies in Australia). In 1926, the Pact Government appointed the Pienaar Commission (chaired by a senior National Party MP, P.J. Pienaar) to examine a comprehensive system of social insurance and assistance. In its first Report, in 1927, the commission recommended the introduction of means-tested old-age and invalidity pensions. But African men and women were excluded, and coloured pensioners were to receive lower benefits than white pensioners. Legislation was passed in 1928, and the first pensions were paid in 1929 (Seekings 2007). 
The most important factor behind the expansion of public provision and care was the imperative-for the National Party_of protecting its "poor white" supporters against gelykstelling (social levelling) and the risk of becoming subordinate to or intermingling with African people. Oldage pensions constituted one cornerstone of the segregationist policies through which the Pact Government sought to raise all-white people to "civilised" standards of living, above, rather than below or alongside, the "native" (African) population. The racial hierarchy had to be maintained. As one National Party Member of Parliament (MP) put it, the "poor white" problem

is a question which not only concerns the poor; it affects the whole white civilisation of this country. It confronts us with the question whether we, the descendants of the staunch old pioneers, will maintain their civilisation and hand it over to our children. ... It may be asked whether there is poverty only in South Africa and whether other countries do not suffer from the same thing. There are poor people everywhere, but the circumstances in South Africa are unique. In Europe poverty has proved a great breeding place for Socialism and Bolshevism. If grievances arise there it is simply an economic matter. In this country, however, there is a small number of whites against the natives, a few civilised people against uncivilised hordes, and for that reason it is so important that not a single white person should be allowed to go under. ${ }^{1}$

These beliefs were not confined to the National Party. In 1933, the first woman elected to Parliament, Leila Reitz, was a member of the South African Party. Reitz, who was active in the emerging field of social work, emphasised in her maiden parliamentary speech that poor (white) families "constitute a danger to the moral life of this country, a danger to themselves, a danger to our social order, our national character, and, in the end, a danger to our white civilization itself". Poor (white) people must be "lifted" up to save "our white civilization". ${ }^{2}$ For most MPs, in most if not all parties, white people were the guardians and agents of modernity in the face of the threats posed by the African majority.

\footnotetext{
${ }^{1}$ Hansard, House of Assembly, 12 August 1924, col. 429-32 (Stals).

${ }^{2}$ Hansard, House of Assembly, 5 June 1933, col. 294-5 (Reitz).
} 
The NGK played a central role in the Afrikaner nationalist movement and National Party in particular. D.F. Malan was a dominee (priest) in the NGK prior to becoming editor of the influential newspaper Die Burger, provincial leader of the National Party, minister in the Pact Government and then national leader in 1934. Malan himself came out of the missionary tradition within the NGK that sought to recruit African people (into racially segregated branches of the NGK) and was even supportive of charity towards the African population as well as white population. In the 1920s and 1930s, Malan — and the NGK, more broadly-came to perceive African people as more of a threat to poor whites, warranting more systematic exclusion and discrimination (Elphick 2012; Koorts 2014).

Whilst the NGK and National Party became increasingly resolute over the exclusion of African people, they also worried about the transfer of responsibilities from church to state. Sections of the NGK and National Party pushed for amendments to the Old Age Pensions Act. The Carnegie Commission into the "poor white problem", established by the NGK not the state, called in its 1932 report for social welfare functions to be shifted back to churches and families. Financial support to the poor should be reduced because it encouraged "dependency". Interventions should address instead the "weak traits" of the poor, including improvidence, thriftlessness, dishonesty and indolence. The NGK succeeded in partially rolling back the old-age pension in the early 1930s by giving officials much more discretion in taking into account the capacity of kin. But modernisers in the National Party (led by Verwoerd) and state fought back. MPs from various parties demanded the expansion of the pension programme, citing cases of deserving constituents who had been denied pensions despite the lack of familial support. "I very much favour the principle that children should provide for their parents", one MP declared, "but ... we can go too far in that direction". ${ }^{3}$ Public provision continued to expand (see Seekings 2008).

${ }^{3}$ Hansard, House of Assembly, 8 June 1933, col. 543-4. 


\section{The Institutionalisation of "Social Policy" Under the Fusion Governments, 1933-1939}

In 1933-1934, economic crisis precipitated the collapse of the Pact Government. A new coalition, comprising most of the National Party together with the South African Party, formed the Fusion Government, and the parties proceeded to merge as the United Party. The basis of the Fusion Government - and United Party_-was the concession by Smuts's South African Party to Hertzog's National Party to deepen racial segregation. The Fusion Government was, politically, a very illiberal administration, although it included prominent liberals in some positions (including, especially, Jan Hofmeyr as minister with responsibility for education, public health [until 1936] and social welfare [from 1936]). In the face of economic crisis and fuelled by improved public revenues (swelled through taxes on the gold mines), ministers expanded existing programmes, including public works programmes, for unemployed white men, subsidies for white farmers (devastated by drought) and poor relief for other poor whites - and then moved towards more innovative government interventions.

In 1934 MPs began for the first time to refer to "social policy" to describe favourably policies to address poverty. A newly elected South African Party MP proposed a motion calling for a "broad social policy" to address the inequities and hardships associated with unemployment. Hofmeyr referred to "the social policy of the Government". Another minister described the introduction of a limited contributory unemployment insurance programme as a component of South Africa's developing "social legislation". ${ }^{4}$

MPs from different parties insisted on the need to relax constraints on the award of old-age pensions to elderly white men and women. "The older people who are not assisted by their children must be the definite care of the Government", asserted one MP. ${ }^{5}$ A senior MP in the National Party-now in opposition-demanded "security" for the poor man and

${ }^{4}$ Hansard, House of Assembly, 27 February 1934, col. 826-57 (Wadley); 17 April 1934, col. 2299 (Hofmeyr); 17 April 1935, col. 5191-2 (Fourie).

${ }^{5}$ Hansard, House of Assembly, 27 February 1934, col. 851-3. 
worker: "To-day we have the position that, in order to get an old age pension, a poor man has to prove that he has no children from whom he can get anything, and who earn sufficient. That is a wrong and humiliating position". ${ }^{6}$ In 1937 the government relaxed some of its restrictions on old-age pensions and lowered the age of eligibility for women from 65 to 60. Between November 1936 and November 1939, the number of white old-age pensioners rose by 55 percent and total expenditure on old-age pensions almost doubled. A series of committees recommended reforms to policies on blind people, children, health insurance and poor relief.

The new "social policies" were institutionalised within a dedicated office for Social Welfare, initially part of the former Department of Labour (renamed the Department of Labour and Social Welfare) then in a new, stand-alone Department of Social Welfare. The new department's approach was, in its understanding of poverty, conservative. In his first report, the new secretary for Social Welfare explained that his department focused on "cultural" aspects of the "rehabilitation" of "socially maladjusted" (white) people. Even if poor white men found employment, they remained in need of the state's help in reforming "their habits, attitudes and interests" (South Africa 1940). The newly appointed (British) Professor of Sociology at the University of the Witwatersrand, John Gray, was struck by what he saw as the resilience of a Calvinist tradition and the perpetuation of a Poor Law tradition (Gray 1937: 278-80). At the same time, the new department saw this cultural poverty as the responsibility of the state, not of the churches. The secretary of Social Welfare himself noted that government policy was now based on "a new conception of duty to the poor arising from the slowly dawning realisation that the poor need not be a liability but that they are a potential asset" (South Africa, 1940: 4). Moreover, science itself could be harnessed to the tasks of rehabilitation, as some of the members of the Carnegie Commission had recognised. The department championed social work rooted in casework and backed up by research. A detailed study of Poverty and Dependency in Cape Town-supervised by (then-Professor) Verwoerd-examined how the "dependent" destitute might be "rehabilitated" (Wagner 1936). The department also oversaw the expansion of social assistance for the blind

${ }^{6}$ Hansard, House of Assembly, 1935, col. 417 (Bremer). 
and invalids. "It is generally accepted that it is the duty of the State to see that its citizens have the opportunity of making a living", explained one MP, adding that "it is doubly the duty of the Government to see that unfit persons shall be given means of existence. It is shameful that people have to beg on the streets". T The new invalidity pensions were-like the old-age pensions - means-tested, taking into account the income of coresident unmarried children (and, in exceptional cases, of children who resided elsewhere also).

Provision for children was also expanded. Pressure from women's, child welfare and liberal organisations (Du Toit 2018) as well as from the handful of (white) women newly elected to Parliament resulted in the appointment of an inter-departmental committee on "Destitute, Neglected, Maladjusted and Delinquent Children" and then, in 1937, a new Children's Act. The new Act provided for care in two main respects, both intended to prevent (white) children becoming "socially maladjusted" or delinquent as a result of growing up in bad conditions at home. First, a battery of measures provided for the state to intervene where children were being neglected and to "rehabilitate" those who were already delinquent. Local officials were empowered to place in a foster home or institution any children who were identified as being "in need of care", including (inter alia) children with absent or delinquent parents, children who were themselves delinquent and-in an acknowledgment of the anxieties of the time-any child that "frequents the company of any immoral ... person, or is otherwise living in circumstances calculated to cause or conduce to its corruption, seduction or prostitution". ${ }^{8}$ The objective, as the Department of Social Welfare explained, was "to conserve for the nation the socially desirable qualities of those persons whose normal development is in danger of being retarded or frustrated through physical or mental defects, social maladjustments or unwholesome environmental stimuli". In implementing these provisions, the department embraced casework and "scientific social analysis" (South Africa 1940: 53), reflecting the new enthusiasm for scientific "poverty knowledge" (Davie 2015). Secondly, the 1937 Act provided for the expanded

\footnotetext{
${ }^{7}$ S.P. Le Roux (Oudtshoorn), Hansard, House of Assembly, 26 March 1936, col. 2056.

${ }^{8}$ Act 31 of 1937 , para 1 .
} 
payment of cash grants-in-aid to poor people caring for children, and to institutions or associations caring for children.

By the late 1930s, South Africa had an extensive system of social assistance providing for sections of the white population, including the elderly, blind and disabled, children and single mothers. Gray, in his inaugural lecture in 1937, assessed that "Today the provision for [the] European population ... is scarcely less complete than that of Great Britain” (Gray 1937: 270). Gray's endorsement overlooked the limited extent of social insurance. The only contributory pension schemes were company- or sector-based, with few members. Unemployment insurance was finally introduced in 1937, but only in selected sectors (Meth and Piper 1984). Poverty among white working-age adults continued to be addressed primarily through public works and farm-support programmes. But the most important difference between South Africa and Great Britain was that the South African welfare state excluded almost entirely the African majority of the population.

The more liberal ministers, MPs and state officials had begun to promote a more inclusive approach. From 1936, pensions were paid to blind African as well as blind white and coloured people. Growing anxiety about juvenile delinquency among African adolescents in town prompted the approval of grants to a slow trickle of African mothers and children (Du Toit 2018: 11-13). The 1937 Committee that drafted the Children's Protection Bill made no distinction on racial grounds, arguing that "the principles underlying the treatment of children "in need of care" or of delinquents are of equal validity whether the children to whom they apply are of one race or another". Whilst there were "special social circumstances which affect the application of these provisions in the case of non-Europeans", it would be a mistake to adopt different standards for the welfare of non-European children. The Committee explicitly recommended the expansion of public provision of institutional care for black children (South Africa 1937: 52-3). When it came to implementation, however, African children continued to be excluded from public programmes (Du Toit 2018).

The exclusion of (or discrimination against) African people was justified using a variety of arguments. The general exclusion of the African majority was based on the perception, among almost all white 
policymakers, that African people were different and inferior, in part because they were seen to be incompletely Christian (practising polygamous marriage and witchcraft) (Chanock 2001). The African population was also viewed increasingly as a threat to the "poor white" population and hence "white civilisation". The more charitable, missionary tradition within the NGK weakened during the 1920s and 1930s (Elphick 2012). With respect to social welfare programmes specifically, the extension of public provision to the African population was widely assessed as impractical and unaffordable (Du Toit 2018). It was also asserted that African people did not need public assistance, either because they had lower needs or because they could be supported by extended kin. The Native Economic Commission found in 1932 that:

The poverty of individuals which occurs among Europeans is not common among Natives. Their communal system cares for all its people. Broadly speaking there is no starvation because each man will share his food with others. ... Such poverty as exists, therefore, applies to the whole of the community among which it occurs, but urban conditions are beginning to break down the communal traditions, and instances were quoted to us of Natives who found it necessary to hide what food they have, because sharing would tend to leave them without the necessaries for their own subsistence. (South Africa 1932: para 998-9)

This argument became a pillar of the ideology of apartheid after 1948: The African population had its own traditions and practices. The Department of Social Welfare denied maintenance grants and "mother's pensions" to African people on the grounds that "under Native law it is the natural duty of the head of the kraal or guardian-at-law to support any minor belonging to his kraal or under his care". Moreover, "the granting of maintenance by the State will probably lead to an evasion of the responsibility resting upon the Natives under their own customs" (quoted in South Africa 1940: 64; see also Du Toit 2018). There was, of course, little evidence for this argument: Poverty was very widespread among African people, and (as in the white population) kin were often either unable or unwilling to assist. This denial of reality was the privilege of the powerful. 


\section{The Experience of War, 1939-1945: External Influences, Local Conditions and "Social Security"}

The Second World War had a major effect in South Africa, as elsewhere across the British Empire and beyond. It precipitated a change of government and political realignment. It forged a political environment in which the government was unusually open to reform. And it introduced new proposals for reform, primarily through the diffusion of new ideas from abroad. The war thus changed the agenda for and the political possibility of reform. At the same time, opposition to public provision strengthened within the opposition National Party, in part through the influence of neo-Calvinist theology from abroad.

The outbreak of war led to the collapse of the Fusion Government and a split in the United Party. Prime Minister Hertzog advocated neutrality but lost a parliamentary vote. Hertzog resigned, the Anglophile Smuts was appointed as Prime Minister, and Hertzog led some (but not all) of his former National Party MPs to reunite with Malan's faction of the former National Party already in opposition. The exit of Hertzog and his supporters allowed the United Party, under Smuts, to tilt in a slightly more liberal direction. Its weak "liberal" wing was led by Hofmeyr, who served as Minister of Finance and intermittently as acting prime minister. Reform was also supported by the rump of the Labour Party. Whilst Hofmeyr was undoubtedly liberal, Smuts himself was more complex. During the war, Smuts made encouraging public speeches about the need to build a better society, including "a better life for all sections of the population", including (explicitly) the "native population". "At the same time he expressed concerns in his private correspondence: "I don't like all this preoccupation with the post-war paradise on earth which makes us all concentrate less on the war and more on schemes which confuse and divide us", he wrote to a close friend in London in early 1943; "it is here [in South Africa] very much as with you [in Britain], where people talk

\footnotetext{
${ }^{9}$ Hansard, House of Assembly, 12 January 1942, col. 5-6 (Smuts).
} 
Beveridge instead of war and Hitler". ${ }^{10}$ Nonetheless, Smuts allowed Hofmeyr the space to proceed with modest reforms, perhaps hoping to defuse the militancy shown by industrial workers-including white, coloured and African workers (Alexander 2000).

The first set of ideas to invigorate debate in South Africa during the war were independent of the war itself. In 1938, New Zealand's Labour Party government enacted universal old-age pensions and other benefits (McClure 1998). The New Zealand "model" was cited frequently in South Africa in 1941-1942 (see Miles-Cadman 1941; Burrows et al. 1942; Batson 1943). Several MPs visited New Zealand and referred to it in parliamentary debates. Introducing a debate on social welfare reforms in January 1942, a Labour Party MP asked explicitly "Can our government do what New Zealand has done?"11

Most reformers did not seek simply to replicate the New Zealand reforms, however. One of the United Party's more liberal MPs, Leslie Blackwell, had been born in Australia, before his family migrated to South Africa when he was ten years old. In the late 1930s he was fascinated with the New Zealand Labour Party's "full-blooded policy of 'Socialism in our time"' (Blackwell 1938). In 1941, Smuts sent him to Australia and New Zealand, charging him (inter alia) with investigating their social security systems. Blackwell returned to South Africa with reservations about the replicability of the New Zealand model:

New Zealand is known throughout the Empire and beyond as the home of social security. It was here that the first full-blooded social security charter was put into operation, and it is here that it is being tested out most thoroughly today, but when I returned to South Africa I told my colleagues that they must be careful not to take it for granted that results arrived at in New Zealand could necessarily be predicted for the Union. New Zealand is a rich pastoral country with a homogeneous population and a high standard of living, without the extremes of wealth which are still to be found in South Africa. It has almost no problem of native or coloured people, and, most important of all, it has operated its social security experiment in times

\footnotetext{
${ }^{10}$ Letter, Smuts to Leo Amery, 21 February 1943, reproduced in J. van der Poel (ed.), Selections from the Smuts Papers, Vol. 6 (Cambridge, 1973), 414.

${ }^{11}$ Hansard, House of Assembly, 6 Jan 1942, col. 3304 (Van der Berg).
} 
of great agricultural prosperity and commercial expansion. (Blackwell 1946: 125)

In the parliamentary debate on social welfare in January 1942, Blackwell (1946: 156-8) argued that comprehensive reforms were not feasible until African people in South Africa earned more.

In the meantime, pressure was building outside of Parliament, through what became known as the "social security movement". In September 1942, an economist and Vice Principal of the Durban Technical College, Joseph Sullivan, organised a Social Security Congress in Durban. Sullivan himself had been born in New Zealand. A team of economists from the University of Natal, led by Professor H.R. Burrows, published a detailed set of proposals (Burrows et al. 1942). Under pressure, Smuts established a Social and Economic Planning Committee to examine economic and social reforms, as well as a Commission of Inquiry into a National Health System.

The publication of the Beveridge Report in Britain in December 1942 further invigorated debate in South Africa. Beveridge was discussed in popular pamphlets (e.g. Sullivan 1942; Batson 1943) and in parliamentary debates (by MPs from diverse parties). In January 1943, Smuts appointed a Social Security Committee, including Burrows, to examine and cost options. Parliament dedicated considerable time to debating social security. In the June 1943 parliamentary election, Smuts and the United Party campaigned around the slogan "A better life for all", holding out a vision of a society in which "there will be no forgotten men" and the spectres of "want, poverty, and unemployment" would be "combated to the best of our ability". With the apparent blessing of the United Party, Sullivan stood successfully for election as an independent MP. In September 1943, the Social Security Committee recommended massive public expenditure on welfare (together with Keynesian macroeconomic policies). The Committee's report used Beveridge's terminology and referred to the new international approach to social security which had the "ultimate aim" of "a comprehensive, unified and socially-adequate security plan under the auspices of the State" (South Africa 1943: 11). Crucially, this would provide for at least some African people. The 1943 report acknowledged that "overcrowding of the Reserves, primitive 
farming methods and low unskilled wages" made it "increasingly difficult" for African people to support their kin. African men and women might not need the "elaborate cash benefits indispensable for a civilised community", but "nominal payments" in cash or kind were now "essential" for the elderly and disabled. The Committee therefore recommended that old-age pensions be extended to the African population.

Support for the extension of old-age pensions was not limited to liberal reformers. The extent of poverty in rural areas-and the failure of migrant workers in towns to provide and care for all of their rural dependents-was of growing concern to the magistrates responsible for rural administration and the employers who sought to recruit labour in rural areas. In addition, policies of "influx control" could not prevent the growth of the urban African population, including women and children. This fuelled anxiety about the decline of marriage and the rise of juvenile delinquency within the African population. African political leadersthrough both the elected but conservative councils in some rural areas and the (at the time) slightly less conservative African National Congress-demanded social citizenship, although they were generally distracted by the more important issue of political citizenship (Sagner 2000; Seekings 2000, 2005; Posel 2005).

Reformers made faltering steps towards extending some social programmes. In 1940, the new Acting Prime Minister Jan Hofmeyr instructed that all applications for grants under the Children's Act, regardless of race, should be assessed on merit. In practice, only applications for urban African children were entertained, and benefits were paid at a much lower level than for white children, probably because of the cost implications (Du Toit 2018). Old-age pensions were introduced for African men and women in both rural and urban areas in 1944, albeit with much lower benefits than for white pensioners. By 1946, there were almost twice as many African pensioners as white pensioners, although total expenditure on white pensioners was higher (Jones 1948: 42). Residential institutions were also established for a very small number of "non-European" men and women. In 1946, the state subsidised nineteen old-age homes for a total of 753 elderly white men and women, but only two homes for 217 "non-European" men and women (Jones 1948: 425). 
In these debates on programmatic reform-in public and in Parliament-three positions predominated. First, there was the proreformist position, articulated outside of Parliament by the various strands of the informal "social security movement" and inside Parliament by the more progressive members of the United Party. Reform here entailed partial deracialisation and expansion of existing programmes. This position was informed by "New Liberal" thought: The laissez-faire, small-government approach of the classic liberals had given way to an appreciation of the need for the government to assume responsibility for tackling various problems that affected society as a whole, including poverty among the elderly and children. The war legitimated these arguments in favour of a more active government. Army service may have radicalised some South Africans (Roos 2003), as it did in New Zealand (Fennell 2017). Classic liberal sceptics tended to keep quiet. A second, also pro-reform position was a more social democratic one, articulated by the very small rump of Labour Party MPs (including van der Berg and Miles-Cadman). The third position — the National Party's — was in flux, as we shall see next. These positions certainly did not exhaust the full range of views within Parliament (or white South African society), but they were the positions articulated publicly. People with other views tended to keep quiet.

The main public opposition to programmatic reforms came from the National Party. The National Party had wavered in its support for an expanding state, especially in the early 1930s, but the modernisers (led by Verwoerd) had prevailed, ensuring that programmes were introduced (and expanded) for white people. The party never accepted, however, that pensions and other programmes should be introduced for African people. Moreover, shifts in the character of Afrikaner nationalism and especially the rise of neo-Calvinist theology within the NGK pushed the National Party to reconsider its support for expanding the welfare state. Until the 1920 s, Stellenbosch was the unchallenged base of Dutch Reformed theology, with a strong emphasis on its evangelical mission. Paternalistic charity was integral to this. Whilst the NGK sought to retain a leading role, the National Party itself had embraced an expanded role for the state in tackling the "poor white" question. In the 1930s, however, the hitherto marginal strand of neo-Calvinist theology, based in the small Gereformeerde 
Dutch Church and its associated university (formerly seminary) in Potchefstroom, gained increasing influence-at the same time as the Transvaal National Party grew in importance relative to the Cape National Party within the (federal) National Party.

The neo-Calvinists were inspired by the thought of the Dutch theologian and politician Abraham Kuyper. Many South African theology students studied at Amsterdam's Free University, founded by Kuyper (with the "Free" meaning free from state control). For Kuyperians, "the fundamental error of European history was a consistent erosion, since the French Revolution, of the sovereignty of God in favour of the autonomy of the individual" (Kinghorn 1997: 143). Kuyper was as critical of liberal individualism as he was of communism. In the late 1930s and early 1940s, some South African neo-Calvinists flirted with national socialism, despite its excessive interest in state power; some assumed leadership positions in the pro-Nazi Ossewa Brandwag, which briefly seemed to offer a more radical alternative to Malan's National Party (Marx 2008). But it was the National Party itself that served as the vehicle through which neo-Calvinist ideas shaped public policy, including over welfare reform. Kuyperian neo-Calvinism was deeply ambivalent about the welfare state-as evident in the speeches of some National Party MPs in Parliament. Whilst the systematic racism of apartheid cannot be attributed to neo-Calvinist theology, the concept of "Christian nationalism" was imported into the ideology of the NGK and National Party from the Netherlands, where Kuyper had used the concept with reference to church-run but state-funded schools (Elphick 2012). The NGK and National Party's evolving approach to social programmes - and what later (in the 1950s) came to be known as the "welfare state"-reveals a clear imprint of neo-Calvinism, perhaps in part because Kuyperian thought accorded with the prior scepticism towards social programmes, which had begun to be evident in the early 1930s. After its electoral victory in 1948, the National Party struggled to reconcile its deep ambivalence over the state's social programmes with the political pressure to expand them (Seekings 2020).

In private, and in the wider white South African society, conservative (as well as openly racist) views were undoubtedly much more widespread than was evident in Parliament. This conservatism had surfaced publicly 
in arguments for social work rather than social assistance in the late 1930s, as we saw above, and in the archival records examined by Du Toit (2018). It is unlikely that the war transformed what most white South Africans really thought. But it did delegitimate the public articulation of conservative and racist views outside of the National Party (and Ossewa Brandwag).

\section{Conclusion}

In South Africa, as elsewhere, political actors had their own ideas about the roles of the state, kin, markets and non-state organisations such as churches. They had their own ideas about the form of social contract linking individual citizens to the state and society, as well as about who was deserving of assistance (whether public or private) and who was not. At the same time, local actors' understanding of who should get what and how were shaped-but not determined — through interactions with ideas from elsewhere. South African reformers, in each of Parliament, state and civil society, were well informed of diverse models of social policy reform, including new programmes (such as old-age pensions and different forms of social insurance) as well as "modern" forms of casework in social work. Policy reforms in Australia, New Zealand and Britain were especially influential, as is evident in official government reports, parliamentary debates and writings by activists in civil society.

Whilst there was no shortage of ideas on the public agenda, most of these were never implemented. The bold visions of social policy set out in the reports of a long series of government commissions and investigative committees-from the Pienaar Commission in the late 1920s to the Gluckman Commission (on a national health service) and the Social and Economic Planning Council in the early 1940s-were not realised. Neither social health insurance nor a national health service was introduced (Marks 1997). Unemployment insurance remained limited (Meth and Piper 1984). Contributory pensions remained privately run (although often mandated by government, hence what I have called elsewhere "semi-social" insurance-Seekings [2002]). Nonetheless, by 1948 South Africa had what was clearly a nascent welfare state: Social assistance and 
unemployment relief (as well as the very much less important workmen's compensation) were being paid to at least 600,000 people, and probably more than 700,000 people, out of a total population of under 12 million. The state was also widely involved in the regulation of the family and interventions to contain delinquency. Expenditure on these social policies was one of the largest items on the government's budget. Moreover, the system has been partially and unevenly extended to African people, albeit with discriminatory benefits. This was a liberal welfare regime, in the sense that the role of the state was residual, providing for people when and only when the market failed (although, as in the wage earners' welfare regimes of Australia and New Zealand-see Castles 1985-the state intervened strongly to raise the wages of white workers). It was less liberal in its continued veneration of the family, although eligibility conditions for pensions and other programmes recognised that families - white or African-were less extended than they were imagined to have been in the past.

This nascent welfare state was shaped by the "power resources" of various local actors. Most obviously, the African majority lacked electoral power and had limited power through the deployment or threat of direct action. White workers had some organisational power, although they were divided between competing unions. They and the less skilled "poor white" population were, however, empowered by their votes. Changes in the voting preferences of white voters brought about changes in government with real consequences for public policy. Industrial employers wielded considerable influence, largely because the government was economically dependent: Few social policy reforms were effected without at least the acquiescence of industrial employers, especially the mining companies. Industrial employers supported the extension of old-age pensions to African people, i.e. to people who would otherwise be the dependents of their employees, but generally resisted the expansion of state-run contributory programmes. (White) farmers also enjoyed massive influence within the National Party, which meant that reforms could be imposed on them more easily when (as in the war years) the National Party was in opposition.

Identifying the political power of different classes or interest groups begs the questions of how these groups understood their interests and 
how they legitimately pursued them in public. In South Africa, raceand racism-shaped all of this. The "social question" could not be separated from South Africa's racial version of the "national question" (nor vice versa). White employers, white farmers and white workers almost always saw themselves as white, with a specific interest in preserving their privileges as white people in an African context. Even liberals' enthusiasm for deracialising policies was paternalistic (when it wasn't simply selfinterested). There was no significant social democratic movement because the racial hierarchy was generally viewed as more important than the relations of production, with the result that there was little solidarity between white workers and other workers. Race shaped even the way in which most reformers tackled the "social question" within the white population, drawing on ideas from other, less racialised contexts. Much of the impetus to the initial introduction of programmes to support the (white) elderly as well as (white) mothers and children as well as attempts to regulate (white) families came from anxiety about the effects of poverty on white solidarity and the racial hierarchy. This view was most pronounced within the National Party but extended also into the Labour Party (at least in the 1920s) as well as sections of the South African Party (and later the United Party). Social democrats opposed to capitalist hierarchy and progressive liberals opposed to a rigid racial hierarchy remained marginal to white politics and, except during the unusual circumstances of the Second World War, policymaking.

Contestation over the social question in South Africa (for a summary of the analysis, see Table 6.1) was also infused with shifting religious beliefs. Heclo noted in very Weberian terms the need to understand the moral and religious convictions of the actual people who built welfare states:

The closer one looks at the lives of the men and women involved in every country, the clearer it becomes that those pushing for changes that academics would later label as social citizenship were people with deeply ethical commitments, usually of a religious nature. The project they set for themselves, each in his or her own way, was to bring social practice into closer alignment with religious/ethical principles of sympathy, brotherhood, and a just humanity. (Heclo 1995: 675) 


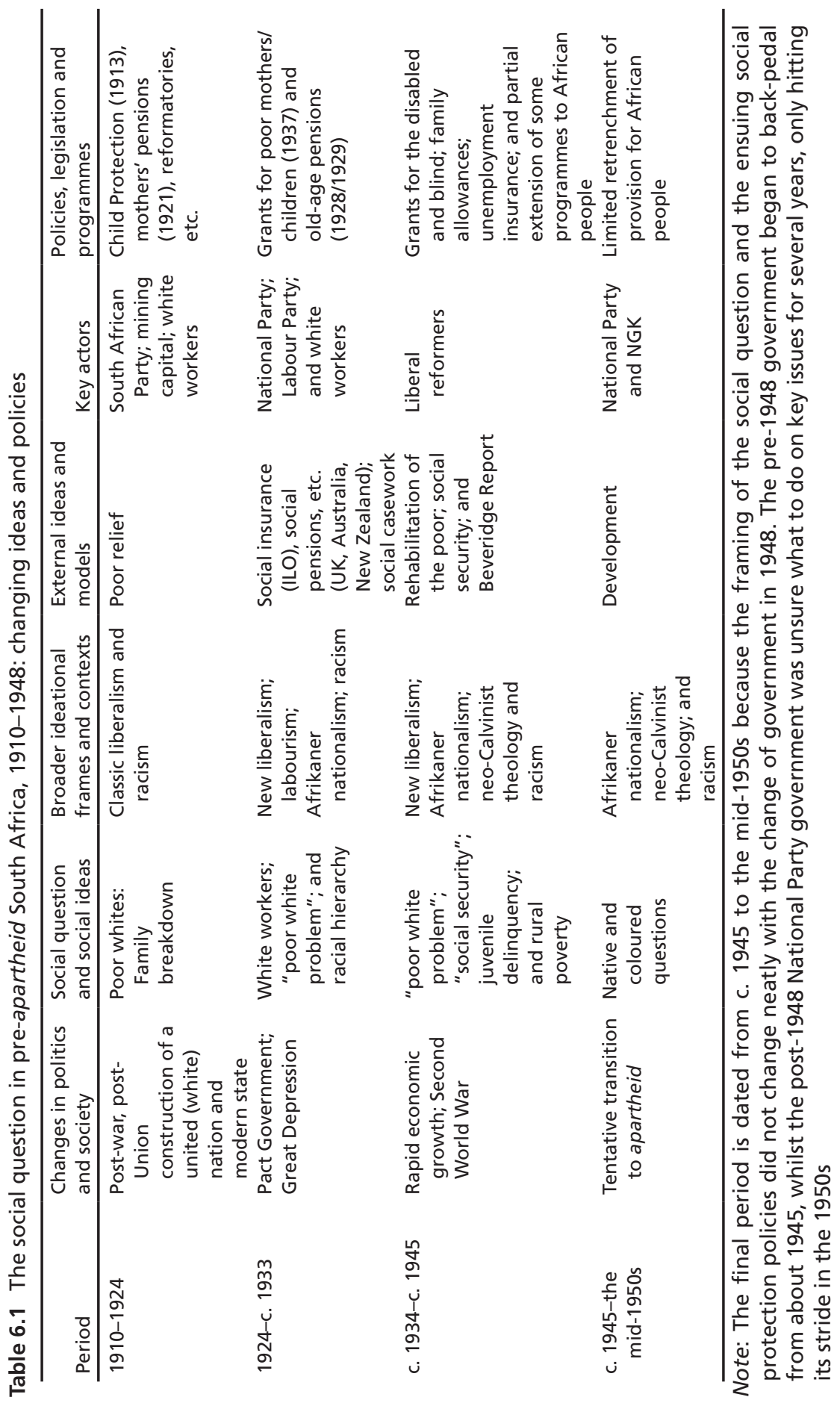


In South Africa, as in Europe (Kahl 2005; van Kersbergen and Manow 2009), the construction of the welfare state was shaped by religious beliefs. Some of the proponents of reform came from more secular backgrounds. Others understood the need for state action through religious lenses. Religious beliefs were especially important for the opponents of reform, first in the 1920s and early 1930s and then again in the 1940s. Whilst the social question was framed in primarily racial terms, religious beliefs inhibited (without forestalling entirely) the statist form of policies to address the social question.

\section{Glossary $^{12}$}

African People of indigenous, African descent, excepting some people included under "coloured" (see below) and including a very small number of people of mixed descent who identified culturally with African people.

Afrikaner The first white settlers in South Africa, many from the Netherlands, others from Germany and France, who embraced an "African" identity during the nineteenth century, speaking Afrikaans, a language rooted in Dutch but remade in the late nineteenth century; in the past Afrikaners were also referred to as "Boers" (literally, farmers), a term now considered derogatory.

Bantu An official apartheid-era and hence derogatory term for African people.

Black A term sometimes limited to African people but sometimes inclusive also of coloured and Indian people.

Coloured A heterogeneous category, including people of "mixed race", people of Southeast Asian descent (mostly "Malay", often Muslim), as well as members of the indigenous Khoi and San populations of the Western and Northern Cape.

Indian South Africans of South Asian descent.

Native An official, largely pre-apartheid term for African people that over time came to be considered as derogatory.

Non-European/Non-white Used before and under apartheid to refer to African, coloured and Indian people; both terms came to be viewed as offensive to black people.

White/European People of European descent, including Afrikaners.

\footnotetext{
${ }^{12}$ South Africa's racialised history had given rise to a host of distinctive terms for different sections of the population.
} 


\section{References}

Alexander, Peter (2000) Workers, war and the origins of Apartheid: Labour and politics in South Africa, 1939-48. Oxford: James Currey.

Batson, Edward (1943) Towards social security: Collected papers on the social services. Cape Town: Paul Koston.

Blackwell, Leslie (1938) African occasions: Reminiscences of thirty years of bar, bench, and politics in South Africa. London: National Book Association and Hutchinson.

Blackwell, Leslie (1946) Farewell to parliament: More reminiscences of bench, bar, parliament and travel. Pietermaritzburg: Shuter and Shooter.

Bottomley, John (1990) Public policy and white rural poverty in South Africa, 1881-1924. Ph.D. thesis, Queen's University, Kingstone.

Burrows, H.R., I.G. Halliday, P.J. de Vos, and R.H. Smith (1942) Social security. South African Journal of Economics 10 (3): 193-247.

Butler, Jeffrey (2017) Charity and welfare in the age of segregation, in Jeffrey Butler, Cradock: How Segregation and Apartheid Came to a South African Town. Charlottesville: University of Virginia Press, 87-104.

Castles, Francis (1985) The working class and welfare: Reflections on the political development of the welfare state in Australia and New Zealand. Sydney: Allen and Unwin.

Centeno, Miguel, and Agustin Ferraro (2013) Republics of the possible: state building in Latin America and Spain. In State and nation making in Latin America and Spain, eds. Centeno and Ferraro, Cambridge: Cambridge University Press, 3-24.

Chanock, Martin (2001) The making of South African legal culture, 1902-1936: Fear, favour and prejudice. Cambridge: Cambridge University Press.

Chisholm, Linda (1990) Gender and deviance in South African industrial schools and reformatories for girls, 1911-1934. In Women and gender in Southern Africa to 1945, ed. Cheryl Walker, Cape Town: David Philip, 293-312.

Davie, Grace (2015) Poverty knowledge in South Africa: A social history of human science, 1855-2005. Cambridge: Cambridge University Press.

Du Toit, Marijke (2018) Mothers' pensions and the "civilised" black poor: The racialised provision of child maintenance grants in South Africa, 1921-1940. Journal of Southern African Studies 44.6: 973-989.

Elphick, Richard (2012), The equality of believers: Protestant missionaries and the racial politics of South Africa. Charlottesville: University of Virginia Press. 
Fennell, Jonathan (2017) Soldiers and social change: The forces vote in the Second World War and New Zealand's great experiment in social citizenship'. English Historical Review 132.554: 73-100.

Freund, Bill (2019) Twentieth century South Africa: A developmental history. Cambridge: Cambridge University Press.

Gray, John L. (1937) The comparative sociology of South Africa. South African Journal of Economics 5: 269-84.

Greenberg, Stanley (1980) Race and state in capitalist development. New Haven: Yale University Press.

Heclo, Hugh (1995) The social question. In Poverty, inequality, and the future of social policy, eds. Katherine McFate, Roger Lawson, and William Julius Wilson, New York: Russell Sage Foundation, 665-92.

Huber, Evelyn, and John Stephens (2012) Democracy and the Left: Social policy and inequality in Latin America. Chicago: University of Chicago Press.

Jones, John Rheinalt (1948) Social welfare In Handbook of Race Relations in South Africa, ed. Ellen Hellman, Cape Town: Oxford University Press, 413-441.

Kahl, Sigrun (2005) The religious roots of modern poverty policy: Catholic, Lutheran and Reformed Protestant traditions compared. European Journal of Sociology 46.1: 91-126.

Kinghorn, Johann (1997) Modernisation and Apartheid: The Afrikaner churches. In Christianity in South Africa: A political, social and cultural history, eds. Richard Elphick and Rodney Davenport, Cape Town: David Philip and Berkeley: University of California Press, 135-154.

Koorts, Lindie (2014) DF Malan and the rise of Afrikaner nationalism. Cape Town: Tafelberg.

Krikler, Jeremy (2005) White rising: The 1922 insurrection and racial killing in South Africa. Manchester: Manchester University Press.

Malloy, James (1979) The politics of social security in Brazil. Pittsburgh: University of Pittsburgh Press.

Marks, Shula (1997) South Africa's early experiment in social medicine: its pioneers and politics. American Journal of Public Health 87.3: 452-459.

Marx, Christoph (2008) Oxwagon Sentinel: Radical Afrikaner nationalism and the history of the Ossewabrandwag. Pretoria: University of South Africa Press.

McClure, Margaret (1998) A civilised community: A history of social security in New Zealand 1898-1998. Auckland: Auckland University Press.

Meth, Charles, and Solveig Piper (1984) Social security in historical perspective. Carnegie Conference Paper 250, Cape Town: University of Cape Town. 
Miles-Cadman, Rev. Cecil Frank (1941) Socialism for South Africa. Cape Town: Rustica Press, for the South African Labour Party.

O'Meara, Dan (1983) Volkscapitalisme: Class, capitalism and ideology in the development of Afrikaner nationalism, 1934-1948.Cambridge: Cambridge University Press.

Posel, Deborah (2005) The case for a welfare state: Poverty and the politics of the urban African family in the 1930s and 1940s. In Worlds of possibility: South Africa in the 1940s, eds. Saul Dubow and Alan Jeeves, Cape Town: Double Storey, 64-86.

Roos, Neil (2003) The Second World War, the army education scheme and the 'discipline' of the white poor in South Africa. History of Education 32.6: 645-659.

Sagner, Andreas (2000) Ageing and social policy in South Africa: Historical perspectives with particular reference to the Eastern Cape. Journal of Southern African Studies 26.3: 523-553.

Seekings, Jeremy (2000), The origins of social citizenship in South Africa. South African Journal of Philosophy 19.4: 386-404.

Seekings, Jeremy (2002) The broader importance of welfare reform in South Africa. Social Dynamics 28.2: 1-38.

Seekings, Jeremy (2005) "Visions and hopes and views about the future": The radical moment of South African welfare reform. In Worlds of possibility: South Africa in the 1940s, eds. Saul Dubow and Alan Jeeves, Cape Town: Double Storey, 44-84.

Seekings, Jeremy (2007) "Not a single white person should be allowed to go under": Swartgevaar and the origins of South Africa's welfare state, 1924-1929. Journal of African History 48.3: 375-94.

Seekings, Jeremy (2008) The Carnegie Commission and the backlash against welfare state-building in South Africa, 1931-1937. Journal of Southern African Studies 34.3: 515-37.

Seekings, Jeremy (2016) State-building, market regulation and citizenship in South Africa. European Journal of Social Theory, 19.2: 191-209.

Seekings, Jeremy (2020) The National Party and the ideology of welfare in South Africa under apartheid. Journal of Southern African Studies 46, 6.

Simons, Jack, and Ray Simons (1969) Class and colour in South Africa. London: Penguin, republished in 1983 by the International Defence and Aid Fund.

Union of South Africa (1932) Report of the Native Economic Commission, U.G. 22 of 1932. Pretoria: Government Printer. 
Union of South Africa (1937) Report of the Interdepartmental Committee on destitute, neglected, maladjusted and delinquent children and young persons, 1934-1937, U.G. 38 of 1937. Pretoria: Government Printer.

Union of South Africa (1940) Report of the Department of Social Welfare for the financial years 1937-1939, U.G. 15 of 1940. Pretoria: Department of Social Welfare.

Union of South Africa (1943) Report of the Social Security Committee, U.G. 14 of 1944. Pretoria: Government Printer.

Sullivan, Joseph (1942) The principles of the Beveridge social security plan, address to Durban Rotary Club. In Joseph Sullivan 1943, Whither South Africa? Social security or eclipse, Durban: Knox, 13-18.

Van der Walt, Lucien (2011) Anarchism and syndicalism in an African port city: the revolutionary traditions of Cape Town's multiracial working class, 1904-1931. Labour History 52.2: 137-171.

Van Kersbergen, Kees, and Philip Manow (eds.) (2009) Religion, class coalitions and welfare states. Cambridge: Cambridge University Press.

Wagner, O.J.M. (1936) Poverty and dependency in Cape Town: A sociological study of 3,300 dependents receiving assistance from the Cape Town General Board of Aid. PhD thesis, University of Stellenbosch.

Open Access This chapter is licensed under the terms of the Creative Commons Attribution 4.0 International License (http://creativecommons.org/licenses/ by/4.0/), which permits use, sharing, adaptation, distribution and reproduction in any medium or format, as long as you give appropriate credit to the original author(s) and the source, provide a link to the Creative Commons licence and indicate if changes were made.

The images or other third party material in this chapter are included in the chapter's Creative Commons licence, unless indicated otherwise in a credit line to the material. If material is not included in the chapter's Creative Commons licence and your intended use is not permitted by statutory regulation or exceeds the permitted use, you will need to obtain permission directly from the copyright holder.

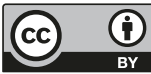

